\title{
Intention to Use Credit Card among College Students in Greater Jakarta
}

\author{
Suresh Kumar \\ sureshkumar@president.ac.id \\ Business Administration Study Program, Faculty of Business \\ President University, Cikarang, Indonesia \\ Lin Karlina \\ karlinaalin98@gmail.com \\ ES Tire \& Bicycle Parts, Cikarang, Indonesia
}

\begin{abstract}
This study aims to determine the influence of the role of parents, financial knowledge, and customer's attitude towards credit card which are determinants of a person's intention to using a credit card. This study applied quantitative data analysis and used an online survey platform as a medium to distribute questionnaires consisting of 22 item statements. A total of 322 responses were collected with 302 valid responses with purposive sampling technique. Structural equation modelling was applied to test the hypothesis. The results of this study indicate that all hypotheses (parents' role, financial knowledge, and attitude) toward intention to use credit card are accepted and the model is also very good where the coefficient of determination is close to one. This study provides a better understanding of customer intentions in determining the purchase decision using a credit card in Greater Jakarta area. This study also provides managerial implications for business and recommendations for future research.
\end{abstract}

Keywords: role of parents; financial knowledge; and customer's attitude; credit card; purchase intention

\begin{abstract}
Abstrak
Penelitian ini bertujuan untuk mengetahui pengaruh peran orang tua, pengetahuan keuangan, dan sikap pelanggan terhadap kartu kredit yang merupakan penentu niat seseorang untuk menggunakan kartu kredit. Penelitian ini menerapkan analisis data kuantitatif dan menggunakan survei daring sebagai media untuk mendistribusikan kuesioner yang terdiri dari 22 butir pernyataan. Sebanyak 322 tanggapan dikumpulkan dengan 302 tanggapan valid dengan teknik purposive sampling. Pemodelan persamaan struktural diterapkan untuk menguji hipotesis. Hasil penelitian ini menunjukkan bahwa semua hipotesis (peran orang tua, pengetahuan keuangan, dan sikap) terhadap niat menggunakan kartu kredit diterima dan modelnya juga sangat baik di mana koefisien determinasi mendekati satu. Penelitian ini memberikan pemahaman yang lebih baik tentang niat pelanggan dalam menentukan keputusan pembelian menggunakan kartu kredit di wilayah Jabodetabek. Studi ini juga memberikan implikasi manajerial untuk bisnis dan rekomendasi untuk peneliti berikutnya.
\end{abstract}

Kata kunci: peran orang tua; pengetahuan; keuangan; sikap pelanggan; kartu kredit; keinginan untuk membeli 


\section{INTRODUCTION}

For many people and industries, credit cards are seen as the savior. For banking industries, credit card usage helps to roll out their money and provide income at the same time. For companies, services and products, it helps their sales because credit card can offer pay later hence, customers do not need to wait till they have case on hand. Certainly for customers, credit card helps them to provide what is important for them at the time needed. No wonder, in 2009 the number of credit card holder in Indonesia was 12,259,295 and in 2019 it has increased up to $30 \%(17,487,057)$ ("credit card growth", 2020) since its first introduction in 1980s ("Sejarah kartu kredit di Indonesia", nd). Whereas the total transactions were around IDR 132 trillion in 2009 and it has increased almost three times as much as in 2019 (IDR 332 trillion) ("credit card growth", 2020).

However, for the last two years, the growth of credit cards has been stagnant due to the tighter restrictions to own it (Khadafi, 2019), the increase usage of digital money or fintech (Agustianti, 2019), limitation acces to financial institutions (Angraini, 2019), the people's purchasing power for durable goods are lower (Gumiwang, 2018), and not to mention the government policy of "peeping" into customers' credit card transactions (Jannah, 2018). Moreover, according to the report of Experian (ac cited in Anggriani, 2019) the credit card usage in Indonesia is the lowest (5\%) among neighbouring countries (Singapura, Malaysia, and Filipina) which are more than $15 \%$, expecially Singapore (35.4\%).

Even though credit card usage gives a lot of benefits, it doesn't come cheap. There has been a shift in people's attitudes towards transition where debt is no longer considered a taboo, leading to increased credit card adoption (Sari and Rofaida, 2011). Further, they say that using a credit card as useful payment such as transactions becomes more secure and practical, and credit cards can use as a source of funding for less cash. But on the other hand, improper use of credit cards can make users more consumptive and get caught up in risky debt practice behavior which makes it struggle with debt (Cloutier and Roy, 2020) which is also supported by the study of Hardekopf (2018) that consumers spend more when using credit cards up to $100 \%$.

Due to its benefits and at the same time the negative impact of not using credit card properly, this study aims to find out the intention to use credit card. This is so to penetrate Indonesian market to compete with neighbouring countries not to mention Indonesia is said to have a demographic bonus.

The study of credit card usage has taken a huge attention by various researchers from various countries, such as Malaysia (Ismail, Amin, Shayeri, and Hashim, 2014; Ahmed, Ismail, Sohail, Tabsh, and Alias, 2010; Amin, 2012; Amin, 2013; Jamshidi and Hussin, 2016), Indonesia (Sari and Rofaida, 2011; Takaendangan, 2015; Lestari, Suharjo, and Muflikhati, 2017; Simanjuntak and Ambar, 2016; Simanullang, 2018; Nugroho, 2017; Muchtar, Kingshott, Wong, and Laksamana, 2012), Sri Lanka (Sriyalatha, 2016; Wickramasinghe and Gurugamage, 2009); Wickramasinghe and Gurugamage (2011); Kuruppuge, Gamage, and Nedelea, 2017), US (Robb, 2011; Robb and Sharpe, 2009; Hancock, Jorgensen, and Swanson, 2013; Norvilitis and Maclean, 2009), China (Wang, 2017; Yao and Meng, 2018; Porto, Huang, and Xiao 2017; Lin, Revindo, Gan, and Cohen, 2019; $\mathrm{Li}, \mathrm{Li}$, and $\mathrm{Li}, 2019$ ).

Most of these studies focus on personal attributes or individual characteristics (Ahmed et al., 2010; Simanjuntak and Rosifa, 2016; Sriyalatha, 2016; Li et al., 2019; Lin et al., 2019) on the course of owning credit cards and fall into a debt. However, as college students, most of them are still under the watch of their parents and not to mention being finance by them as well. Hence, parents provide an important role in the continuity of children's finances (Caruana and Vassallo, 2003). Moreover, they say that parental conduct, for example, 
shopping together and assessing elective money related conditions incredibly influences the view of a kid's buying. Contrary to financial knowledge supporters (Kamil, Musa, and Sahak, 2014; Limbu, 2017; Nugroho, 2017; Wickramasinghe and Gurugamage, 2012), Jorgensen, Rappleyea, Schweichler, Fang, and Moran (2016) mention that having only financial knowldege won't do much on young adults, since they see the world as how they are taught by their parents. It is also supported by the study of Cloutier and Roy (2020) that undergraduate students' behaviour in using credit card is significantly influenced by their parents. Similarly, Tang (2016) mention that parents are sources from whom children develop their skills, knowledge, and attitudes especially financial behaviour.

Hence, this study aims on confirming the factors influencing intention of using credit cards based on role of parents and financial knowledge as the exogenous variables mediating by attitude. It is expected that this study would contribute to the body of knowledge regarding credit card usage intention based on the role of parents, financial knowledge, and attitude factors. It is also expected that this study would give an insight for companies who launch credit card how to get to college students to own the credit card for their business sustainability. The rest of the study is organized: first, literature review on the constructs (role of parents, financial educations, attitude, and intention to use) and the relationship among them. Second is the method of the study following the results and discussions of the findings. Last but not least is the conclusion and recommendation for future research and policy makers and credit card companies.

\section{LITERATURE REVIEW}

\subsection{Intention to Use Credit Card}

According to Sari and Rofaida (2011), intention is the willingness of a person to do or not to do something which may change due to time and condition of that person. In the credit card context, the willingness can be owning the credit card, use it for transactions, and even increase the frequency to use it. In addition, Wang (2017) states that the more positive of a person toward credit card will give higher intention to use it and even increase the frequency of using it. Contrary to Wang (2017), Robb (2011) states that a more knowledgeable person toward financial knowledge would use less credit card compare to less knowledgeable one. Nevertheles, Limbu (2017) states that credit card knowledge and the ability to control will influence the intention to use or misuse credit card.

\subsection{Role of Parents}

Jorgensen et al. (2016), stand that children's financial view depends on their observation and participation of their parents' including financial education. They further state that the involvement of parents declines in line with various stages of economic status from getting their first employement till being retired or resigned. In addition, Tang (2016) reveals that the main person introducing financial behaviour to children is their parents because most children spend their time at home compare to their experience at work or high school education. Tang's finding is supported by Hancock et al. (2013) where role of parents and education are the supporting factor credit card usage attitude not the working experience. Moreover, Cloutier and Roy (2020) believe that parents have a very important role in undergraduate's personal finance where the pressure of parents leads to a more responsible financial behaviour and unwillingness to borrow. Contrary to Tang (2016) and Hancock et al. (2013), Zsótér and Bauer (2019) reveal that even though parents are involve in the process of financial behaviour from their children such as giving pocket money, building desire, indulgence, being a good example, and sharing about finances, children's experiences are also giving huge impact on their financial behaviour. Hence, this study proposes: 


\section{$H_{1}$ : Role of Parents has a positive influence towards credit card usage intention.}

\subsection{Financial Knowledge}

According to Shim, Barber, and Card (2010) financial socialization is the process of acquiring knowledge, skills, attitudes and behavior of financial knowledge through parents, college, and job consciously or unconsciously starting their childhood to adult life. In addition, Takaendengan (2015) refers financial knowledge as the ability of a person know how to get money from several resources as well as manage it. Thus, introducing personal financial knowledge must be done earlier, such as at high school level, because it is the main aspect in decision making among consumers (Ismail et al., 2014; Kumar, Watung, Eunike, and Liunata, 2017). This is to the fact that most college students appear not to well acquanted with financial behavior (Putri and Kumar, 2014; Tehae and Kumar, 2019). Hence, most debts appear to be made by college students (Norvilitis and Maclean, 2009), However, they further state that financial education from previous studies in UK, US, and New Zealand found to give some impact to decrease the debts as well as their study in US. Contrary to Norvilitis and Maclean, Hancock et al. (2013) found a conflict finding between researches who support that financial education really help college students to avoid debts in credit card and those who see that credit cards should not be given to college students due to their inadequate knowledge in money management and control of needs. Further, they found that financial education is the most important factor to increse the credit card usage attitude . In addition, Ismail et al. (2014) also found that knowledge of credit card is an important factor that need to be considered to increase the attitude of credit card usage among college students. In addittion, Takaendangan (2015) also reveals that financial knowledge plays the major role in credit card usage decision among undergraduate students in Indonesia which is similar to the findings of Wickramasinghe and Gurugamage (2012) in Sri Lanka. Hence, this study proposes:

\section{$\mathrm{H}_{2}$ : Financial knowledge has a positive influence towards credit card usage attitude.}

$\mathrm{H}_{3}$ : Financial knowledge has a positive influence towards credit card usage intention.

\subsection{Credit Card Attitude}

Ismail, Amin, Shayeri, and Hashim (2014) acknowledge that credit card is a payment gateway that the payment can be paid at a later time cash or instalment after acquiring the good or services at the time required. They also acknowledge that consumers use credit card for the individual needs such as home instalments, cars, electronic, households, and even loans for business. Hancock et al. (2013) believe that a positive attitude towards credit card will increase the possession of more credit cards and the use of them, however, the negative attitude towards credit card will create a reluctant attitude to acquire one not to mention use it. According to Sari and Rofaida (2011) credit card attitude is depends on a person perception how helpful it is, how easy to use, or even how fun it is to use. Helpful in this case is whether it does what it is meant to do in a very simple way, instead of complicated and at the same time it is enjoyable that it can fulfil one's desire when he/she needs it at once. Amin (2013) reveals that the intention to use credit card increases along with the increment of credit card usage attitude. In addition, Jamshidi and Hussin (2017) found that attitude is the major contributor in increasing the intention to use credit card among bank customers. In addition, Sari and Rofaida (2011) also reveals that attitude of credit card usage plays an important role on credit card usage intention among students. Hence, this study proposes:

\section{$H_{4}:$ Credit card usage attitude has positive influence toward credit card usage intention.}




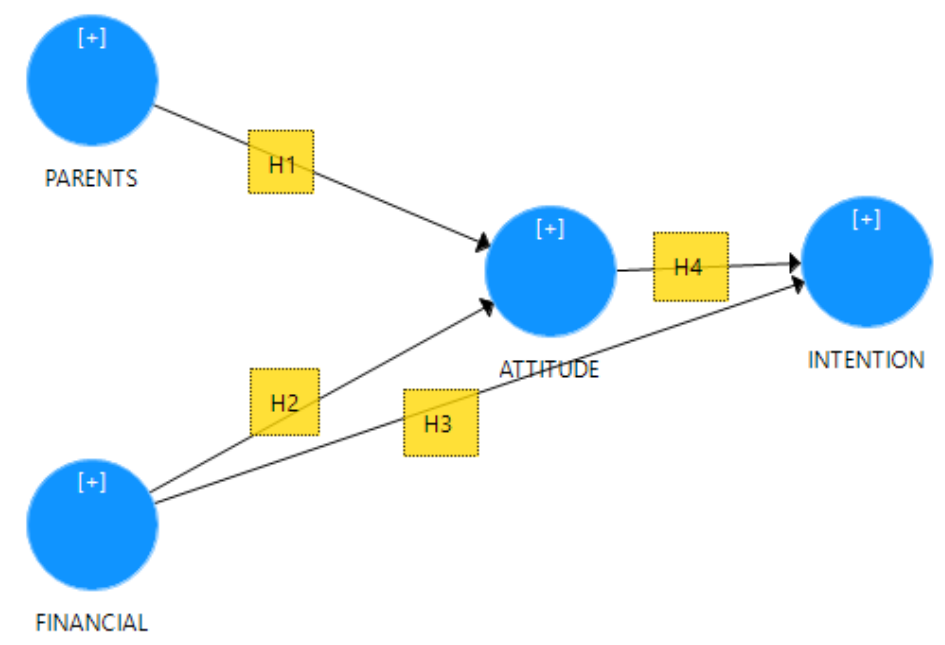

Figure 1. Research Framework

Source: Hancock et al. (2013), Robb (2011), Amin (2013), and Jamshidi and Hussin (2017)

\section{RESEARCH METHOD}

The population of this study was those who lived in the Greater Jakarta area (Jakarta, Bogor, Depok, Tangerang, and Bekasi), aged over 21 years and owned credit cards. In this study, Purposive sampling technique was used since some criteria were applied, such as respondents had to be at least 21 years old, live in Greater Jakarta, own at least one credit card and have used at least once for the last 6 months. According to Malhotra, Nunan, and Birks, (2017), a sample size of more than 300 is considered good, hence 400 samples were distributed to reach the required sample size. Method of research chosen was quantitative data analysis since the aim of the research was to confirm the relationship among variables that build credit card usage intention. Survey was used to gather data by means of questionnaire since it is the best way to generalize population based on small sample to draw conclusion of populatin's characteristic (Creswell, 2014). Questionnaires were distributed through social media platforms, such as Line, Instagram, WhatsApp, and several credit card communities on Facebook directly to gather respondents' perception. Hence, this study adopted cross sectional data analysis. The questionnaires were developed from various studies, such as Robb (2011) for financial knowledge with five item statements, Hancock et al. (2013) for credit card attitude with four item statements and the role of parents with five item statements, Amin (2013) and Jamshidi and Hussin (2017) for intention with five item statements and three item statements respectively.

The quantitative data analysis method applied to test the hypothesis was structural equation modelling-partial least square (SEM-PLS) since it is to predict the intention behavior of credit card usage based on financial knowledge, role of parents, and attitude toward credit card usage. According to Hair, Hult, Ringle, and Sarstedt (2017), SEM-PLS is a data analysis technique that can analyze non-normal distribution data, prediction oriented, and based explained variance. Before hypothesis is tested, composite realibility and convergent validity of the data are checked with the criteria greated than 0.7 and 0.5 respectively. Further, discriminant validity based on Fornell-Larcker is adapted with the criteria square root of average variance extracted is greater than correlation among variable (Hair et al., 2014). For hypothesis testing, the criteria are checked through $\mathrm{p}$ value with less than 0.05 , then reject null hypothesis and accept alternate hypothesis. The t-statistic is also checked with the criteria greater than 1.96 (for 95\% confidence interval), then reject null hypothesis and accept alternate hypothesis. Mulitcollinearity of the data is also checked with VIF less than 5 (Hair, Black, Babin, and Anderson, 2018). 


\section{RESULTS AND DISCUSSION}

\subsection{Respondents' Profile}

Respondents who filled out the questionnaire were 322 people around Greater Jakarta and only 302 responses were able to completely fill up the questionnaire. The questionnaire results showed that most respondents are male (59\%) compare to women (40.1\%). Most of them are aged $21-25$ years (45.7\%), followed by the age group of 26-30 years $(28.8 \%)$, then there are also age groups of 31-35 years (16.9\%), then ages 36-40 years (5\%), and over 40 years $(3.6 \%)$. As for the education level, most respondents are a bachelor degree holder $(60.3 \%)$ and the remaining are high school graduates $(33.1 \%)$, and the least are those who have completed the Master Degree level (6.6\%). From the marital status, most of the respondents are singles (59.6\%) and the rest are married $(40.4 \%)$ with majority are employees (48.3\%), followed by self-employed (32.8\%), and entrepreneurs (18.9\%). As per their income, it shows that most respondents are at IDR 7,000,000 - IDR 10,000,000 (25.5\%), followed by IDR 3,800,000 - 7,000,000 (28.1\%), more than IDR 15,000,000 (16.2\%), IDR 10,000,000 - IDR 15,000,000 (15.9\%) and the last is less than IDR 3,800,000 $(14.2 \%)$.

\subsection{Reliability and Validity}

In order to reach adequate composite reliability and convergent validity, some items were removed from the analysis. They are one item from attitude construct (ATT4), two items from financial knowledge (FK2 and FK4), one item from role of parents (ROP2), and four items from intention (INT1, INT 2, INT 6, and INT 7). Thus the composite reliability is achieved (greater than 0.7 ) with the lowest reliability value (0.754) is attitude and the highest one $(0.815)$ is role of parents (Table 1$)$. The convergent validity is also achieved (greater than $0.5)$ where financial knowledge has the highest convergent value $(0.576)$ and attititude has the lowest one (0.510). As for the factor loadings are in adequate value from 0.591 till 0.808 (Table 1). Apart of convergent validity, discriminant validity was also tested with FornellLarcker criterion, and resulted in no discriminant problem since the diagonal value (square root of AVE) is higher compare to the correlation among variables (Table 2).

\subsection{Hypothesis testing and R-Square}

Once data were reliable and valid, the next step is testing the hypothesis. Based on the results, the first hypothesis (role of parents towards attitude) is proven to be significant (t-stat $=4.402 ; \beta=0.273 ; \mathrm{p}=0.000)$. This finding is inline with result from Norvilitis and MacLean (2010), Hancock (2013), Tang (2016), Jorgensen et al. (2016) and Cloutier and Roy (2020). The theory supports parents to keep an eye on their children regarding credit card issues. The role of parents greatly helps reduce the financial problems of children and parents also have the right solution in terms of financial knowledge.

The second hypothesis (financial knowledge towards attitude) is also proven to be significant ( $\mathrm{t}-\mathrm{stat}=8.634 ; \beta=0.487 ; \mathrm{p}=0.000$ ). Previous studies (Kamil, Musa, and Sahak, 2014; Limbu, 2017; Nugroho, 2017; Wickramasinghe and Gurugamage, 2012) have shown that financial knowledge has a major influence on customer behavior towards credit cards which is also proven by this study. It also reveals that financial knowledge is the most important factor compare to the role of parents.

The third hypothesis (financial knowledge towards intention) is also proven to be significant $(\mathrm{t}$-stat $=2.171 ; \beta=0.177 ; \mathrm{p}=0.030)$. Previous research has proven that how financial knowledge influences a person's intention to decide on purchase using a credit card in Manado (Takaendengan, 2015) and Sri Lanka (Wickramasinghe and Gurugamage, 2012). Hence, someone who has good financial knowledge tends to conduct more positive financial 
management behaviors and use more financial products and services.

Last but not the least is the fourth hypothesis (attitude towards intention) is also proven to be significant $(\mathrm{t}-\mathrm{stat}=5.791 ; \beta=0.465 ; \mathrm{p}=0.000)$. This finding is inline with the findings of Sari and Rofaida (2011), Jamshidi and Hussin (2017), and Amin (2013) that the intention to use credit card comes from the attitude of credit card usage.

The model built for intention to use a credit card based on parents' role, financial knowledge, and attitude shows a good model since the coefficient of determination is close to one $\left(\mathrm{R}^{2}=47.2 \%\right)$ (Table 4$)$. This also means there are other factors $(52.8 \%)$ that influence the intention to use credit card which are not being studied here.

Table 1. Factor Loadings, Composite Reliability, Convergent Validity Resuls

\begin{tabular}{lrrr}
\hline INDICATORS & \multicolumn{1}{l}{$\begin{array}{l}\text { FACTOR } \\
\text { LOADINGS }\end{array}$} & $\begin{array}{l}\text { COMPOSITE } \\
\text { RELIABILITY }\end{array}$ & $\begin{array}{l}\text { VALIDITY } \\
\text { (AVE) }\end{array}$ \\
\hline ATT1 & 0.727 & 0.754 & 0.510 \\
ATT2 & 0.591 & & \\
ATT3 & 0.807 & & \\
FK1 & 0.808 & 0.802 & 0.576 \\
FK3 & 0.803 & & \\
FK5 & 0.656 & & \\
INT3 & 0.685 & 0.809 & 0.515 \\
INT4 & 0.653 & & \\
INT5 & 0.726 & & \\
INT8 & 0.799 & & \\
ROP1 & 0.758 & 0.815 & 0.526 \\
ROP3 & 0.684 & & \\
ROP4 & 0.678 & & \\
ROP5 & 0.776 & & \\
\hline
\end{tabular}

Source: SMARTPLS 3.0 Output

Table 2. Discriminat Validity Results using Fornell-Larcker Criterion

\begin{tabular}{lrrrr}
\hline & ATTITUDE & FINANCIAL & INTENTION & PARENTS \\
\hline ATTITUDE & 0.714 & & & \\
FINANCIAL & 0.652 & 0.759 & & \\
INTENTION & 0.580 & 0.479 & 0.718 & \\
PARENTS & 0.567 & 0.604 & 0.512 & 0.725 \\
\hline
\end{tabular}

Source: SMARTPLS 3.0 Output

Table 3. Hypothesis Results

\begin{tabular}{lrrr}
\hline & ESTIMATE & $\begin{array}{l}\text { T Statistics } \\
(\mid \mathrm{O} / \mathrm{STDEV})\end{array}$ & \multicolumn{1}{l}{ Values } \\
\hline $\begin{array}{l}\text { ATTITUDE -> } \\
\text { INTENTION }\end{array}$ & 0.465 & 5.791 & 0.000 \\
$\begin{array}{l}\text { FINANCIAL -> } \\
\text { ATTITUDE }\end{array}$ & 0.487 & 8.634 & 0.000
\end{tabular}




\begin{tabular}{lcrl} 
FINANCIAL -> & 0.177 & 2.171 & 0.030 \\
INTENTION & & & \\
$\begin{array}{l}\text { PARENTS -> } \\
\text { ATTITUDE }\end{array}$ & 0.273 & 4.402 & 0.000 \\
\hline \multicolumn{4}{r}{ Source: SMARTPLS 3.0 Output }
\end{tabular}

Table 4. R-Square Results

\begin{tabular}{lrr}
\hline & R Square & R Square Adjusted \\
\hline ATTITUDE & 0.472 & 0.469 \\
INTENTION & 0.354 & 0.350 \\
\hline
\end{tabular}

Source: SMARTPLS 3.0 Output

\section{CONCLUSION}

Based on the results of the analysis, it was found that all hypotheses were supported. It means that in building intention for credit card usage, the role of parents, financial knowledge, and attitude are the most important factors. The result also reveals that the most important factor to increase the attitude of credit card usage is the financial knowledge instead of the role of parents as this study believes in the beginning. Hence, this study contributes to the body of knowledge regarding credit card usage intention based on the role of parents, financial knowledge, and attitude factors.

This research has proven that financial knowledge is the most influencial factor for credit card usage. However, the importance of credit card itself is not well known among youngsters except for it is used for pay later. Hence, the credit card issuers can start going from college to college or even senior high school to give seminar regarding financial knowledge, expecting in the future that these youngsters are able to manage their finance with full responsibility especially while using credit card.

This research has also proven that the role of parents influences a person's intention to use a credit card. Therefore, it is important for credit card issuers to recommend credit cards to parents for their 21-year-old child and above. So far most credit card issuers have been in a right track by providing credit cards to the family members, such as wife and children, but under the husband's name. However, by knowing the family members date of birth, in this case is the children, they can offer the credit cards once the child becomes an adult as a gift on their birthday. They can also give an attractive package such as going for a vacation or products to be bought using a credit card to attract those young adults to own a credit card.

In addition, this study has also proven that attitudes toward credit cards influence a person's intention to continue using a credit card. This means that customers will continue to use credit cards if the cost of using a credit card is not too high because customers will be afraid if they cannot pay credit card bills. For this reason, credit card issuers can provide affordable interest or refinance if they have difficulties in paying the debts instead of chasing them with debt collectors. Credit card issuers need also to work with other companies to provide discount or installment, with maybe no interest, for items which are popular among youngsters, such as gadgets. Another way is to give reward to customers who have used a credit card for a period of time determined by the credit card issuers.

Since they are other factors that could contribute more than fifty percentages, for future research is expected to explore other varibles such as personal characteristics (Li et al., 2019; Lin et al., 2019) and behavioral beliefs (Ismail et al., 2014). Behavioral beliefs may give an interesting perspective looking at the condition where most Asians are religious believers. 
Indonesia is a big archipelago, istead of Greater Jakarta; future researhers can duplicate the study to other metropolitan cities, such as Surabaya, Medan, Bali, Yogyakarta etc.

\section{REFERENCES}

Ahmed, Z., Ismail, I., Sohail, S., M., Tabsh, I. and Alias, H. (2010). Malaysian consumers' credit card usage behaviour. Asia Pacific Journal of Marketing and Logistics, 22 (4), 528-544. https://doi.org/10.1108/13555851011090547

Agustianti (2019, August 13). Transaksi kartu kredit semester I tumbuh 1,15\%, diduga tersaingi fintec. Katadata.co.id. Jakarta retrieved from

https://katadata.co.id/berita/2019/08/13/transaksi-kartu-kredit-semester-i-tumbuh-115diduga-tersaingi-fintech.

Amin, H. (2012). Patronage factors of Malaysian local customers toward Islamic credit cards. Management Research Review, 35(6), 512-530. https://doi.org/10.1108/01409171211238271

Amin, H. (2013). Factors influencing Malaysian bank customers to choose Islamic credit cards: Empirical evidence from the TRA model. Journal of Islamic Marketing, 4(3), 245-263. https://doi.org/10.1108/JIMA-02-2012-0013

Angraini, D. (2019, January 18). Experian: Pengguna kartu kredit di Indonesia Baru 5\%. Medcom.id. Jakarta. Retrieved from https://www.medcom.id/ekonomi/mikro/VNxqAXxb-experian-pengguna-kartukredit-di-indonesia-baru-5.

Caruana, A. and Vassallo, R. (2003). Children's perception of their influence over purchases: the role of parental communication patterns. Journal of Consumer Marketing, 20(1), 55-66. https://doi.org/10.1108/07363760310456955

Cloutier, J. and Roy, A. (2020). A consumer credit use of undergraduate, graduate and postgraduate students: An application of the theory of planned behaviour. J Consum Policy. https://doi.org/10.1007/s10603-019-09447-8

Credit Card Growth. (2020, March 24). Retrieved from https://www.akki.or.id/index.php/credit-card-growth.

Creswell, J.W. (2014). Research design, qualitative, quantitative, and mixed method approach, fourth edition, Sage Publication, Inc.

Hair, J. F., Black, W., Babin, B., \& Anderson, R. (2018). Multivariate data analysis (8th ed.). Boston, MA: Cengage Learning EMEA.

Hair, J. F., Hult, G. T. M., Ringle, C. M., \& Sarstedt, M. (2017). A primer on Partial Least Squares Structural Equation Modeling (PLS-SEM), 2nd Ed. (2nd ed.). Thousand Oaks: Sage.

Hancock, A.M., Jorgensen, B.L., and Swanson, M.S. (2012). College students and credit card use: The role of parents, work experience, financial knowledge, and credit card attitudes. J Fam Econ. DOI 10.1007/s10834-012-9338-8

Hardekopf, B. (2018, July 16). Do people really spend more with credit cards? Forbes. https://www.forbes.com/sites/billhardekopf/2018/07/16/do-people-really-spend-morewith-credit-cards/\#355edbe71c19

Ismail, S., Amin, H., Shayeri, S.F., and Hashim, N. (2014). Determinants of attitude towards credit card usage. Jurnal Pengurusan, 41, 145 - 154.

Jamshidi, D. and Hussin, N. (2016). Forecasting patronage factors of Islamic credit card as a new e-commerce banking service: An integration of TAM with perceived religiosity and trust. Journal of Islamic Marketing, 7(4), 378-404. https://doi.org/10.1108/JIMA07-2014-0050 
Jorgensen, B.L., Rappleyea, D.L., Schweichler, J.T. (2017). The financial behavior of emerging adults: A family financial socialization approach. J Fam Econ, 38, 57-69. https://doi.org/10.1007/s10834-015-9481-0

Kamil, N. S. S., Musa, R., and Sahak, S. Z. (2014). Examining the role of financial intelligence quotient (FiQ) in explaining credit card usage behavior: A conceptual framework. Procedia - Social and Behavioral Sciences, 130, 568 - 576.

Khadafi, M. (2019, January 31). Pertumbuhan kartu kredit 2 tahun terakhir stagnan. Business.com. Jakarta. Retrieved from https://finansial.bisnis.com/read/20190131/90/884547/pertumbuhan-kartu-kredit-2tahun-terakhir-stagnan.

Kumar, S., Watung, C., Eunike, J., \& Liunata, L. (2017). The influence of literacy towards financial behavior and its implication on financial decision: A survey of President University Student in Cikarang-Bekasi. FIRM: Journal of Management Studies, 2(1), 14-23.

Kuruppuge, R. H., Gamage, S. K. N., and Nedelea, A. M. (2017). Credit cards as a determinant of social capital: A study of rational behaviour of urbanised consumers. Ecoforum, 6(1).

Lestari, B. A., Suharjo, B., Muflikhati, I. (2017). Minat kepemilikan kartu kredit (Studi kasus kota Bogor). Jurnal Aplikasi Bisnis dan Manajemen, 3(1).

Limbu, Y.B. (2017). Credit card knowledge, social motivation, and credit card misuse among college students: examining the information-motivation-behavioral skills model. International Journal of Bank Marketing, 35(5). doi: 10.1108/ IJBM-04-2016-0045

Li, Y., Li, Y., and Li, Y. (2019). What factors are influencing credit card customer's default behavior in China? A study based on survival analysis. Physica A: Statistical Mechanics and Its Applications. doi:10.1016/j.physa.2019.04.097

Lin, L., Revindo, M.D., Gan, C., and Cohen, D. A. (2019). Determinants of credit card spending and debt of Chinese consumers. International Journal of Bank Marketing, https://doi.org/10.1108/IJBM-01-2018-0010

Lin, L., Revindo, M., Gan, C. and Cohen, D. (2019). Determinants of credit card spending and debt of Chinese consumers. International Journal of Bank Marketing, 37(2), 545564. https://doi.org/10.1108/IJBM-01-2018-0010

Malhotra, N. K., Nunan, D., \& Birks, D. F. (2017). Marketing research an applied approach (5th ed.). Philadelphia, PA: Trans-Atlantic Publications, Inc.

Muchtar, F., Kingshott, R. P. J., Wong, D., and Laksamana, P. (2012). A purchase intention model for foreign banks within Indonesia. International Journal of Bank Marketing, 30(6), 452-464. doi:10.1108/02652321211262212

Norvilitis, J.M. and Maclean, M.G. (2009). The role of parents in college students' financial behaviors and attitudes. Journal of Economic Psychology, 31, 55-63.

Nugroho, J.E. (2017). Factors of credit card usage on e-commerce: A case of Indonesian millennials in Jakarta (Bachelor thesis, President University, Bekasi, Indonesia). Retrieved from http://repository.president.ac.id/handle/123456789/748.

Porto, N., Huang, Y., and Xiao, J. J. (2017). Credit card adoption and usage in china: urbanrural comparisons. The Singapore Economic Review, 1743010. doi:10.1142/s021759081743010x

Putri, Y. K., \& Kumar, S. (2014). The influence of financial education, social and motivation toward personal financial behavior: A survey of undergraduate student in Java. In Asia-Pacific Social Science Conference (pp. 148-156). APSSC, Seoul-Korea.

Robb, C.A. (2009). Effect of personal financial knowledge on college students' credit card behavior. Journal of Financial Counseling and Planning, 20(1). 
Robb, C.A. (2011). Financial knowledge and credit card behavior of college students. J Fam Econs, 32, 690-698. DOI 10.1007/s10834-011-9259-y

Sari, M. and Rofaida, R. (2011). Factors affecting the behavior of university community to use credit card. International Research Journal of Business Studies, 4(3), 217-228.

Sejarah Kartu Kredit di Indonesia (nd). Retrieved from http://www.mafiakartukredit.com/2011/06/sejarah-kartu-kredit-di-indonesia.html

Shim, S., Barber, B.L., Card, N.A. (2010). Financial socialization of first-year college students: The roles of parents, work, and education. J Youth Adolescence, 39, 14571470. https://doi.org/10.1007/s10964-009-9432-x

Simanjuntak, M. and Ambar S. R. (2016). Self-esteem, money attitude, credit card usage, and compulsive buying behaviour. Economic Journal of Emerging Markets, 128135. DOI:10.20885/ejem.vol8.iss2.art5

Simanullang, L. (2018). Indonesian bankers' spending behavior toward credit card in Jakarta (Bachelor thesis, President University, Bekasi, Indonesia). Retrieved from http://repository.president.ac.id/handle/123456789/238

Sriyalatha, M. A. K. (2016). Determinants of customers'attitude towards credit card usage: lessons learned from academics in Sri Lanka. Case Studies in Business and Management, 3(2), 19-37. http://dx.doi.org/10.5296/csbm.v3i2.9664

Takaendengan, L. A. (2015). The influence of personal financial knowledge and personal financial attitude towards buying decision using credit card in Manado City. Jurnal Berkala Ilmiah Efisiensi, 15(4), 171-181.

Tehae, S., \& Kumar, S. (2019). The influence of financial experience, financial literacy, financial behavior, and financial condition toward financial knowledge and its implication on financial distress: A survey on employees in Pontianak. CV. Rasi Terbit.

Tang, N. (2016). Like father like son: How does parents' financial behavior affect their children's financial behavior? Journal of Consumer Affairs, 51(2), 284311. doi:10.1111/joca.12122

Wang, Y. (2017). Consumer credit card use intention and influence factors analysis. MATEC Web of Conferences 100, 05073. DOI: 10.1051/ matecconf/20171000507.

Wickramasinghe, V. and Gurugamage, A. (2009). Consumer credit card ownership and usage practices: Empirical evidence from Sri Lanka. International Journal of Consumer Studies, 33(4), 436-447. doi:10.1111/j.1470-6431.2009.00779.x

Wickramasinghe, V. and Gurugamage, A. (2012). Effects of social demographic attributes, knowledge about credit cards and perceived lifestyle outcomes on credit card usage. International Journal of Consumer Studies, 36(1), 80-89. doi:10.1111/j.14706431.2010.00993.X

Yao, R. and Meng, X. (2018). Credit card usage among students in China. Journal of Financial Counseling and Planning, 29(2). DOI: 10.1891/1052-3073.29.2.304

Zsótér, B. and Bauer, A. (2019). The importance of institutional trust for financial service providers among young adults and their parents in an emerging market. Society and Economy, 41 (2), pp. 211-225. DOI: 10.1556/204.2019.005 